\title{
Obtaining doubled haploid lines of the Lr19 gene using anther cultures of winter wheat genotypes
}

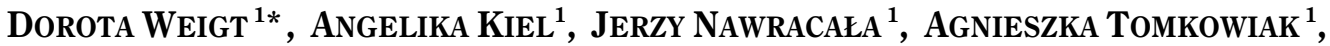

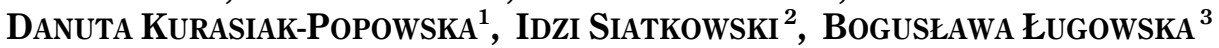 \\ ${ }^{1}$ Department of Genetics and Plant Breeding, Poznań University of Life Sciences, Poznań, Poland \\ ${ }^{2}$ Department of Mathematical and Statistical Methods, Poznań University of Life Sciences, Poznań, Poland \\ ${ }^{3}$ DANKO Plant Breeding Ltd.
}

\begin{abstract}
Leaf rust pathogens are able to overcome plants' resistance by the appearance of new races. Therefore, an introduction of leaf rust resistance genes into highyielding wheat genotypes is essential. One of such genes is Lr19 (leaf rust resistance gene) that could be a source of resistance in polish breeding programs. The aim of this study was to obtain doubled haploid lines of the $\operatorname{Lr} 19$ gene in anther cultures of winter wheat genotypes. In the experiment, $\mathrm{F}_{3}$ generation plants from two cross-combinations were used: genotype T39 $\times$ Ozon and genotype T36 $\times$ Hondia (T36 and T39 lines carry Lr19 gene). Three combinations of growth regulators such as 2,4-D; 2,4-D and dicamba; and 2,4-D and kinetin were applied. A total of 13,550 anthers were tested. The embryo-like structures were formed at an average frequency of $9.95 \%$ and were mainly influenced by the genotype, not by the composition of hormones in induction media. Regeneration frequency of green plants was recorded to be $1.45 \%$. The highest frequency of green plant regeneration was observed on induction media supplemented with 2,4-D and dicamba reaching $1.79 \%$. Spontaneous doubled haploids tested by laser flow cytometry were detected in $33.95 \%$ of plants. The frequency of the formation of embryo-like structure was mainly influenced by the genotype, not by the composition of hormones in induction media.
\end{abstract}

Key words: wheat, leave rust, androgenesis, regeneration frequency, doubled haploids

\section{Introduction}

Leaf rust disease is caused by the fungus Puccinia triticina. It infects all grain crops and wild grasses and causes a loss of about $10 \%$ in the global grain production every year. Meanwhile, this value can reach even $30 \%$ per year in Poland. Such a high loss in yields can be partially attributed to the weather conditions that decide about the severity of disease symptoms. Moreover, different varieties may show increased sensitivity to leaf rust pathogen (Kryczyński and Weber, 2011). The most environmentally friendly and the cheapest method of controlling leaf rust disease is breeding of resistant varieties of wheat. Unfortunately, rust pathogens are able to overcome plants' resistance by the appearance of new races. Moreover, the effectiveness of resistance genes in fighting against leaf rust disease depends on the composition of the pathogen population (McIntosh et al., 1995).
So far, over 70 leaf rust resistance genes ( $L r$ genes) have been identified in various plants (McIntosh et al., 2010). Lr19, originating from the wild Agropyron elongatum, is effective on leaf rust races occurring in Poland; therefore, introducing this gene into polish cultivars could prove to be very beneficial in diminishing losses in the yield. In order to accelerate the selection for resistance to leaf rust, plants are brought to the haploid stage by androgenesis. Doubled haploids (DH) obtained by in vitro cultures are fully homozygous and can be selected using molecular markers. The selection of $\mathrm{DH}$ lines is easier than the selection of hybrids because the phenotype of homozygous plant is equivalent to the genotype (Baenziger et al., 2001). Furthermore, androgenesis in breeding programs will most probably shorten the time required to obtain new resistant lines, particularly in the case of self-pollinating wheat. 
There are several ways to produce haploid plants: parthenogenesis and apogamy; anther and microspore cultures; chromosome elimination techniques; and finally, ovary cultures (Kasha, 2005). Of the abovementioned approaches, anther and microspore cultures as well as chromosome elimination techniques appear to be the most effective and the most popular (Hussain et al., 2012). Anther cultures are not only effective but also convenient, allowing the production of many haploid plants from one anther. However, this method has a very serious disadvantage: it is strongly genotype dependent (Niroula and Bimb, 2009).

The first anther culture (androgenesis) phenomenon in wheat has been reported in 1973, but doubled haploid cultivar of wheat was received only in 1986 (Pauk et al., 1995). Currently, although the DH lines are used more often in breeding programs, there is still a need to develop more efficient methods for obtaining such lines.

The aim of the study was to obtain doubled haploid lines from anther cultures of winter wheat genotypes with $\operatorname{Lr} 19$ gene determining resistance to leaf rust.

\section{Materials and methods}

\section{Donor plant material}

In the experiment, wheat plants (Triticum spp.) of the $\mathrm{F}_{3}$ generation from two cross-combinations were used: T39 $\times$ Ozon cultivar and T36 $\times$ Hondia cultivar (T36 and T39 lines carry Lr19 gene increasing the resistance to leaf rust in polish growth conditions). The plant material was obtained from Danko PB Ltd. where both crossing and preliminary experiments for the resistance of T36 and T39 lines to leaf rust were carried out (data not published).

\section{Research method}

The donor tillers were cut, and the spikes were kept in Erlenmeyer flasks in tap water and put in the dark for cold pretreatment at $4{ }^{\circ} \mathrm{C}$ for 7 to 14 days. Before isolation, microspore developmental stage was checked under a microscope by squashing anthers in a drop of acetocarmine staining (Barnabas et al. 2001) and examined. The spikes containing uninucleate microspores were surface-sterilized with $4.85 \% \mathrm{NaClO}$ for 4 minutes and then rinsed thrice with sterile distilled water for 5 minutes each. Anthers were transferred onto the C17-inducing medium according to the protocol by Wang and Chen
(1983) with modifications (Weigt et al. 2012). Three combinations of growth regulators were applied: 2,4-dichlorophenoxyacetic (2,4-D) $(2.0 \mathrm{mg} / \mathrm{l}) ; 2,4-\mathrm{D}(1.0 \mathrm{mg} / \mathrm{l})$ with dicamba $(1.0 \mathrm{mg} / \mathrm{l})$; and $2,4-\mathrm{D}(1.5 \mathrm{mg} / \mathrm{l})$ with kinetin $(0.5 \mathrm{mg} / 1)$. Fifty anthers without filaments from a single spike were plated per dish. A total of 13,550 anthers were cultured $-4,300$ anthers from the $\mathrm{F}_{3}$ plants of $\mathrm{T} 39$ $\times$ OZON as well as 9,250 anthers from the $F_{3}$ plants of T36 $\times$ HONDIA.

The anthers were incubated in the dark at $28^{\circ} \mathrm{C}$. Depending on the developmental rate, 4-12 weeks after isolation, the embryo-like structures were transferred to MS (Basal Salt Mixture) regeneration medium (Murashige and Skoog, 1962) supplemented with $30000 \mathrm{mg} / \mathrm{l} \mathrm{saccha-}$ rose and $0.5 \mathrm{mg} / 1 \mathrm{NAA}$ (1-naphthaleneacetic acid) and $0.5 \mathrm{mg} / \mathrm{l}$ kinetin. The dishes were incubated for 3-4 weeks in the culture room $(16 / 8 \mathrm{~h} \mathrm{light} /$ dark $)$ at $24^{\circ} \mathrm{C}$. After the 1 -week incubation, green and albino plantlets emerged.

\section{Determination of ploidy level}

The ploidy level of green plantlets (with an approximate height of $10 \mathrm{~cm}$ ) growing on MS medium was analyzed before colchicine treatment. DNA content was measured by laser flow cytometry at the Kutnowska Hodowla Buraka Cukrowego Ltd. in Straszków according to the methodology described by Śliwińska (2008) (Fig. 5). For the analysis, young leaves of regenerated plants and of internal standard were chopped simultaneously with a sharp razor blade in a plastic Petri dish with $1 \mathrm{ml} \mathrm{nu-}$ cleus-isolation buffer $\left(0.1 \mathrm{M}\right.$ Tris, $2.5 \mathrm{mM} \mathrm{MgCl}_{2} 6 \mathrm{H}_{2} \mathrm{O}$, $85 \mathrm{mM} \mathrm{NaCl}, 0.1 \%$ Triton X-100; pH 7.0), supplemented with propidium iodide $(50 \mathrm{mg} / \mathrm{ml})$ and ribonuclease A (50 $\mathrm{mg} / \mathrm{ml}$ ) for nuclear DNA content estimation. The genome of Ozon cultivar was used as an internal standard. After chopping, the suspension was passed through a mesh nylon filter and incubated for approximately 30 minutes. Following the incubation, a staining buffer ( $50 \mu \mathrm{g} / \mathrm{ml}$ propidium iodide) was added and measurements were taken using a flow cytometer Partec equipped with an argon laser.

\section{Chromosome doubling}

Haploid plants were placed for $7 \mathrm{~h}$ in a $0.1 \%$ colchicine solution with an addition of Tween 20 (10 drops/1 l). Next, the plants were washed with tap water for $12 \mathrm{~h}$ and planted into pots with soil. The plants, after the colchicine treatment, were vernalized for 8 weeks in a cool 


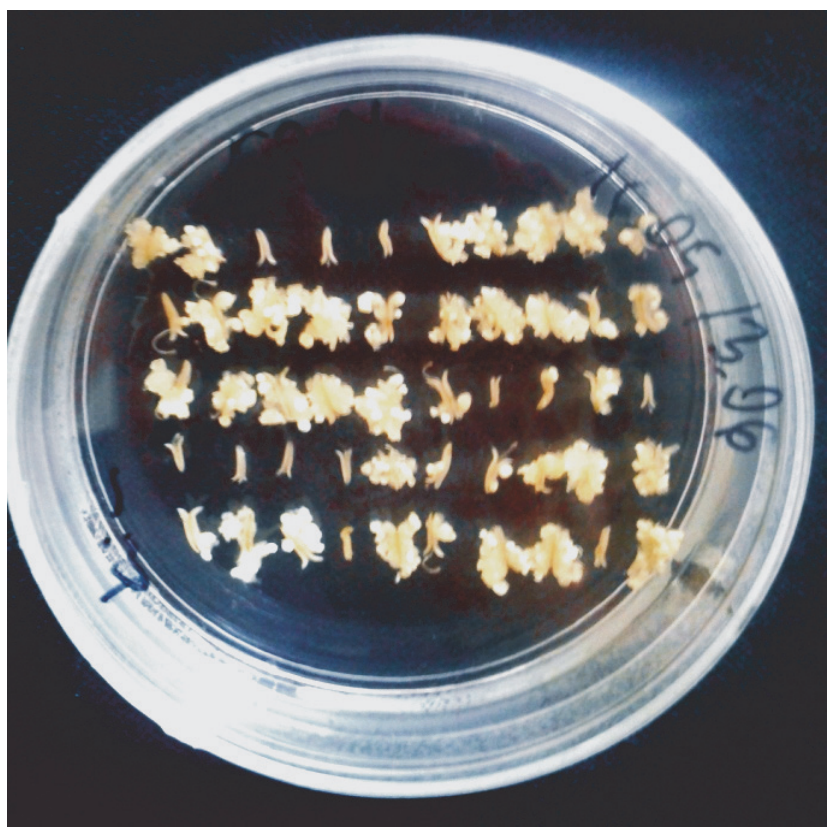

Fig. 1. Globular structure formed on $\mathrm{C} 17$ induction medium supplemented by 2,4-D and kinetin

chamber at $2^{\circ} \mathrm{C}$, in a dim light. The plants that set seeds were considered as $\mathrm{DH}$.

\section{Analysis of the results}

To estimate the effect of genotype and hormones on the regeneration of plantlets, the following traits were determined: frequency of the formation of embryo-like structure expressed as a number of embryo-like structures produced per 100 cultivated anthers, regeneration frequency of green plant expressed as a number of green plants regenerated per 100 cultivated anthers, regeneration frequency of albino plant expressed as a number of albino plants regenerated per 100 cultivated anthers, and the ratio of green to all plants, i.e., a number of green plants regenerated per all plants. All parameters were expressed in percentage.

To assess the degree of precision, standard deviations for the studied traits were calculated. Furthermore, two-factor analysis of variance with interaction was applied to investigate the influence of genotypes and compositions of growth hormones in the induction medium on the number of embryo-like structures, the number of green plants and albino plants. Statistical calculations were performed with $\mathrm{R}$ software, version 3.2.1 (R Core Team, 2015).

\section{Results}

The analysis of androgenic responsiveness among studied wheat genotypes showed a variation in frequency of the formation of embryo-like structure, green and albino plant regeneration, and green to all plants' ratio (Table 1). The frequency of the formation of embryo-like structure of T36 $\times$ Hondia $\mathrm{F}_{3}$ generation plants was almost two times higher in comparison with T39 $\times$ Ozon plants (11.58\% and 6.44\%, respectively) (Figs. 2, 3). The regeneration frequency of green plants (Fig. 4) was similar in both tested cross-combinations, amounting almost to $1.5 \%$. The frequency of albino plants' regeneration was more than three times lower in $\mathrm{T} 39 \times \mathrm{Ozon}_{3}$ plants than in T36 $\times$ Hondia plants (Fig. 5).

There are differences in the ratio of green to all plants between the two analyzed cross-combinations. Almost two times higher green to all plants' ratio was observed in T39 × Ozon plants (Table 1). Standard deviations of frequency of the formation of embryo-like structure and frequency of plants' regeneration were high. The plant growth regulators added into the induction media did not influence the frequency of formation of embryo-like structures in studied genotypes (Table 2). For all three combinations of growth hormones, the frequency of embryo-like structure formation was similartotal frequency of androgenesis induction ranged from $9.43 \%$ to $10.31 \%$. T39 $\times$ Ozon $\mathrm{F}_{3}$ genotypes produced more embryo-like structures per 100 anthers (8.13) on induction medium supplemented with the $2,4-\mathrm{D}$ as opposed to T36 $\times$ Hondia plants that regenerated better on the medium containing 2,4-D + dicamba (12.49). There were differences in the frequency of green plant regeneration depending on the plant growth regulators that were present in the induction medium. The green plants' production was the highest on induction medium supplemented with dicamba (total of $1.79 \%$ ) and the lowest on the medium containing 2,4-D only (total of 1.01\%) in both studied genotypes. Statistical analysis showed significant influence of genotype on the induction of androgenesis (Table 3), but not on plant regeneration (Tables 4 and 5). The combination of hormones in induction medium had neither significant influence on embryo-like structure formation nor on plant regeneration (Tables 3-5).

The ploidy level was determined for 162 from 196 regenerated green plants (34 plants did not survive the 
Table 1. Genotypic response to in vitro anther culture of wheat hybrids

\begin{tabular}{|c|c|c|c|c|c|c|c|c|c|c|c|}
\hline \multirow{3}{*}{ Genotype } & \multirow{3}{*}{$\begin{array}{l}\text { Number } \\
\text { of culti- } \\
\text { vated } \\
\text { anthers }\end{array}$} & \multicolumn{3}{|c|}{ Embryo-like structures } & \multicolumn{6}{|c|}{ Regenerated plants } & \multirow{3}{*}{$\begin{array}{c}\text { Green to all } \\
\text { plants ratio } \\
{[\%]}\end{array}$} \\
\hline & & \multirow[b]{2}{*}{ No. } & \multirow{2}{*}{$\begin{array}{c}\text { Frequency } \\
{[\%]}\end{array}$} & \multirow[b]{2}{*}{$\sigma$} & \multicolumn{3}{|c|}{ Green } & \multicolumn{3}{|c|}{ Albino } & \\
\hline & & & & & No. & $\begin{array}{c}\text { Frequency } \\
{[\%]}\end{array}$ & $\sigma$ & No. & $\begin{array}{c}\text { Frequency } \\
{[\%]}\end{array}$ & $\sigma$ & \\
\hline T39 × Ozon & 4300 & 277 & 6.44 & 9.20 & 64 & 1.49 & 3.48 & 21 & 0.49 & 1.21 & 75 \\
\hline T36 $\times$ Hondia & 9250 & 1071 & 11.58 & 13.69 & 132 & 1.43 & 2.76 & 174 & 1.88 & 3.71 & 43 \\
\hline Total & 13550 & 1348 & 9.95 & & 196 & 1.45 & & 195 & 1.44 & & 50 \\
\hline
\end{tabular}

\section{$\sigma-$ standard deviation}

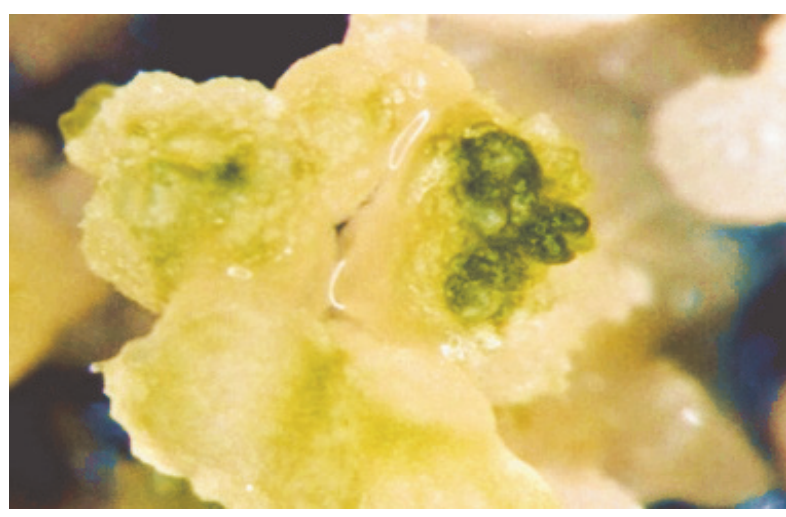

Fig. 2. Embryo-like structure with shoot apical merystem of T36 x Hondia plant growing on MS regeneration medium

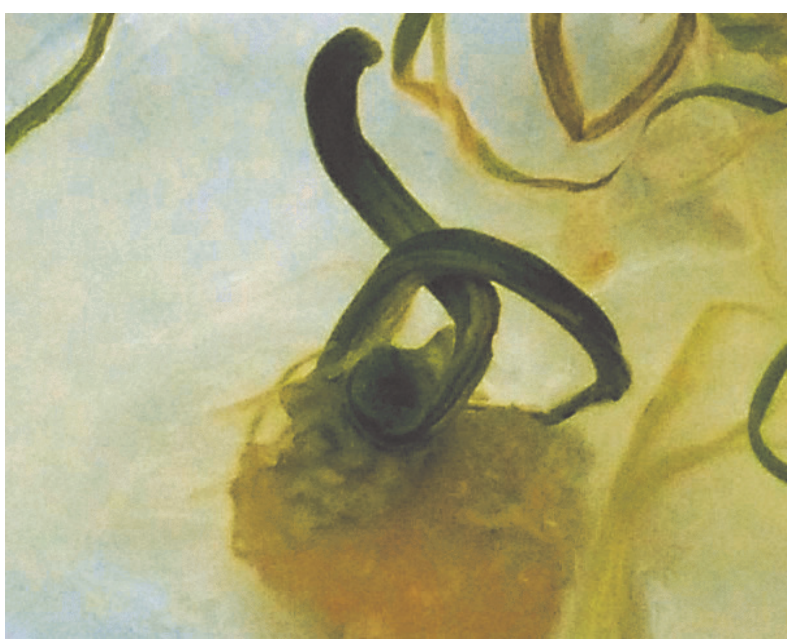

Fig. 3. Green plant of T39 x Ozon cross combination growing on the MS regeneration medium

transfer to the soil) before colchicine treatment (Fig. 5, Table 6). Most of tested regenerates were haploids (59.88\%). The analysis of the number of spontaneous $\mathrm{DH}$, in contrast to haploids, revealed the differences between tested genotypes. The percent of haploid plants from T36 $\times$ Hondia cross was more than twice higher

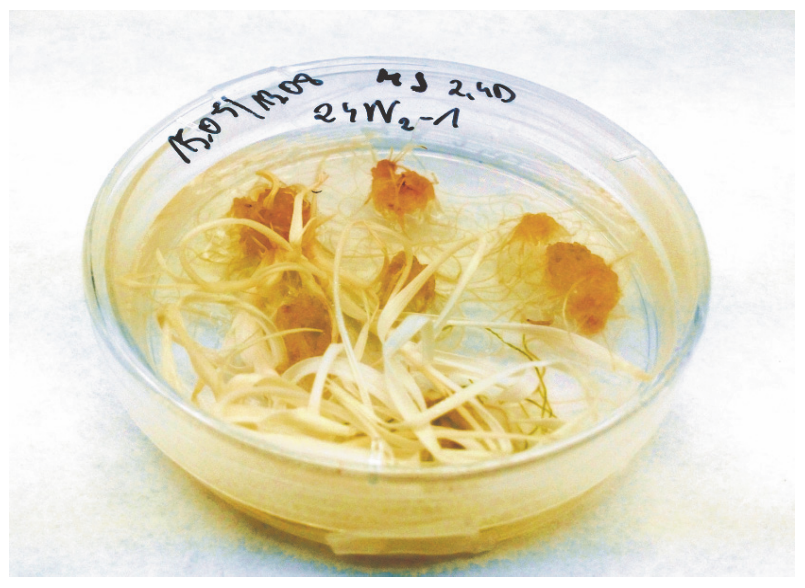

Fig. 4. Albino plant of T39 x Ozon cross combination growing on the MS regeneration medium

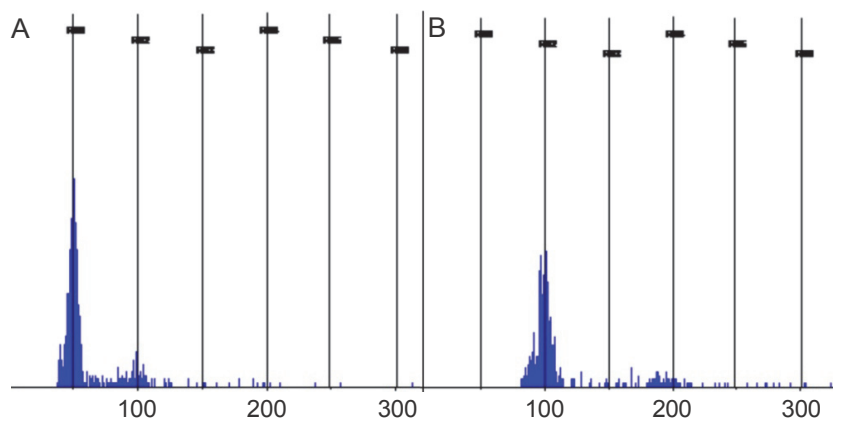

Fig. 5. A: Flow-cytometry analysis of haploid plant, $\mathrm{B}$ : doubled haploid plant

than of doubled haploid regenerates, but in T39 $\times$ Ozon genotype, the haploids and DH were nearly equally numerous. It was found that 6 plants from T39 $\times$ Ozon and 4 from T36 $\times$ Hondia were aneuploidy $(6.17 \%$ of all tested plants).

Among 97 haploid plants, which were treated by colchicine solution, 34 formed seeds, of which 13 plants were from the T39 $\times$ Ozon and 21 from the T $36 \times$ Hondia cross. 
Table 2. The influence of hormones in induction medium on androgenic response of wheat genotypes

\begin{tabular}{l|c|c|c|c|c|c}
\hline \multirow{2}{*}{ Genotype } & \multicolumn{2}{|c|}{ Embryo-like structure frequency [\%] } & \multicolumn{2}{c}{ Green plant regeneration frequency [\%] } \\
\cline { 2 - 7 } & $\begin{array}{c}\text { C17 medium } \\
+2,4-\mathrm{D} \\
(2.0 \mathrm{mg} / \mathrm{l})\end{array}$ & $\begin{array}{c}\text { C17 medium } \\
+2,4-\mathrm{D}(1.0 \mathrm{mg} / \mathrm{l}) \\
+ \text { dicamba } \\
(1.0 \mathrm{mg} / \mathrm{l})\end{array}$ & $\begin{array}{c}\text { C17 medium } \\
+2,4-\mathrm{D}(1.5 \mathrm{mg} / \mathrm{l}) \\
+ \text { kinetin } \\
(0.5 \mathrm{mg} / \mathrm{l})\end{array}$ & $\begin{array}{c}\text { C17 medium } \\
+2,4-\mathrm{D} \\
(2.0 \mathrm{mg} / \mathrm{l})\end{array}$ & $\begin{array}{c}\text { C17 medium } \\
+2,4-\mathrm{D}(1.0 \mathrm{mg} / \mathrm{l}) \\
+ \text { dicamba } \\
(1.0 \mathrm{mg} / \mathrm{l})\end{array}$ & $\begin{array}{c}\text { C17 medium } \\
+2,4-\mathrm{D}(1.5 \mathrm{mg} / \mathrm{l}) \\
+\mathrm{kinetin} \\
(0.5 \mathrm{mg} / \mathrm{l})\end{array}$ \\
\hline T39 $\times$ Ozon & 8.13 & 4.93 & 6.07 & 1.29 & 1.71 & 1.48 \\
\hline T36 $\times$ Hondia & 11.14 & 12.49 & 10.93 & 0.86 & 1.83 & 1.50 \\
\hline Total & 9.84 & 10.31 & 9.43 & 1.01 & 1.79 & 1.46 \\
\hline$\sigma$ & 12.47 & 11.97 & 12.34 & 2.20 & 3.44 & 3.32 \\
\hline
\end{tabular}

$\sigma-$ standard deviation

Table 3. Two factor analysis of variance with interaction shown influence of genotypes and combinations of hormones in induction medium on calli regeneration

\begin{tabular}{l|c|c|c|c|c}
\hline \multicolumn{1}{c|}{ Source } & Df & SumSq & MeanSq & $F$-value & $P$-value \\
\hline Genotype & 1 & 1097 & 1097.22 & 5.133 & $0.025^{*}$ \\
\hline Medium & 2 & 61 & 30.74 & 0.144 & 0.866 \\
\hline Genotype* Medium & 2 & 201 & 100.58 & 0.471 & 0.625 \\
\hline Residuals & 201 & 42964 & 213.75 & & \\
\hline
\end{tabular}

Signif. codes: ‘” 0.05

Table 4. Two factor analysis of variance with interaction shown influence of genotypes and combinations of hormones in induction medium on green plants regeneration

\begin{tabular}{l|c|c|c|c|c}
\hline \multicolumn{1}{c|}{ Source } & Df & SumSq & MeanSq & $F$-value & $P$-value \\
\hline Genotype & 1 & 2.00 & 1.998 & 0.440 & $0.508^{*}$ \\
\hline Medium & 2 & 13.40 & 6.701 & 1.476 & 0.231 \\
\hline Genotype* Medium & 2 & 4.73 & 2.365 & 0.521 & 0.595 \\
\hline Residuals & 201 & 912.29 & 4.539 & & \\
\hline
\end{tabular}

Signif. codes: ‘” 0.05

Table 5. Two factor analysis of variance with interaction shown influence of genotypes and combinations of hormones in induction medium on albino plants regeneration

\begin{tabular}{l|c|c|c|c|c}
\hline \multicolumn{1}{c|}{ Source } & Df & SumSq & MeanSq & $F$-value & $P$-value \\
\hline Genotype & 1 & 56.7 & 56.656 & 3.292 & $0.071^{*}$ \\
\hline Medium & 2 & 5.3 & 2.652 & 0.154 & 0.857 \\
\hline Genotype $^{*}$ Medium & 2 & 14.5 & 7.236 & 0.421 & 0.657 \\
\hline Residuals & 201 & 3458.9 & 17.208 & & \\
\hline
\end{tabular}

Signif. codes: “*’ 0.05 
Table 6. Ploidy level of regenerants of analyzed wheat genotypes

\begin{tabular}{l|c|c|c|c|c|c|c}
\hline \multirow{2}{*}{ Genotype } & \multirow{2}{*}{$\begin{array}{c}\text { Number } \\
\text { of tested plants }\end{array}$} & \multicolumn{2}{c|}{ Haploids } & \multicolumn{2}{c|}{ Doubled haploids } & \multicolumn{2}{c}{ Aneuploids } \\
\cline { 3 - 8 } & & No. & $\%$ & No. & $\%$ & No. & $\%$ \\
\hline T39 $\times$ Ozon & 49 & 22 & 44.90 & 21 & 42.86 & 6 & 12.24 \\
\hline T36 $\times$ Hondia & 113 & 75 & 66.37 & 34 & 30.09 & 4 & 3.54 \\
\hline Total & 162 & 97 & 59.88 & 55 & 33.95 & 10 & 6.17 \\
\hline
\end{tabular}

\section{Discussion}

Genotype dependency and albinism limit the wide application of anther cultures in practical wheat breeding (Rybczyński et al., 1991; Marciniak et al., 2003; Broughton, 2011; Redha and Suleman, 2011; Lantos et al., 2013). In this study, the frequency of formation of embryo-like structure was shown to be influenced by the genetic background. Kondić-Špika and coworkers' (2011) work and our results indicate the importance of using particular embryonic genotypes in breeding programs. In such way, in vitro androgenic response could be transferred from a cultivar with a good ability to regenerate to its $\mathrm{F}_{1}$ hybrids (Kim et al. 2003). The donor plant genotype is controlled by a complex of genes with quantitative inheritance. Kondić-Špika and coworkers (2008) suggested that expensive tissue culture techniques should concentrate on responsive plant material breeding combinations, while unresponsive material should be improved via crossing.

It was found that individual chromosomes of wheat influence their ability to undergo androgenesis. For example, 4B chromosome of wheat has a stimulatory effect on the induction of this process. In turn, green plant regeneration is controlled by wheat $2 \mathrm{~A}, 2 \mathrm{~B}, 3 \mathrm{~A}$, and $5 \mathrm{~B}$ chromosomes (Torp et al., 2001). Moreover, an introgression of alien chromosomes leads to the changes in wheat's androgenic ability. The presence of rye $1 R, 3 R$, and $7 \mathrm{R}$ chromosomes in the substitute wheat-rye lines has stimulating effect on the induction of androgenesis, whereas $5 \mathrm{R}$ rye chromosome inhibits the formation of androgenic embryoids (Dobrovolskaya et al., 2001, 2003). Pershina and coworkers (2013) conducted a comparative analysis of the ability of two wheat cultivars carrying the 7DL-7Ai chromosome translocation sequence (Omskaya 37 and Omskaya 38) to androgenesis. It has been observed that wheat-rye translocation sequence stimulated the induction of androgenesis in rye; however, the presence of this translocation sequence in wheat genome inhibits androgenesis. According to Sibikeeva and coworkers (2004), when wheat-wheatgrass translocation involving 7DL-7Ai sequence (carrying the Lr19 gene) from Agropyron elongatum was present in wheat genome, the induction of embryogenesis and green plant regeneration was affected. They tested three hybrids, with two of them revealing significantly lower green plant regeneration than the other studied genotypes. Sibikeeva and Sibikeev (1996) studied anther culture response in wheat carrying alien translocations and stated that the translocation with $L r g$ and $\operatorname{Lr} 19$ decreased the frequency of formation of embryo-like structures and the regeneration frequency of green plant. On the contrary, Sibikeeva and Sibikeev (2014) investigated other combinations of translocating genes in near isogenic lines and showed that a combination of $L r 9$ with Lr19 and $L r 19$ with $L r 24$ genes decreased the frequency of formation of embryo-like structure but increased the regeneration frequency of green plant. In turn, the combination of $L r 19$ with $L r 26$ and $L r 19$ with $L r 25$ increased both these parameters. In addition, the Lr26 and $\operatorname{Lr} 19$ gene combination decreased the regeneration frequency of albino plant. Pershina and coworkers (2013) suggested that the presence of an appropriate alien translocation sequence and genotypic environment of studied genotype has an impact on the manifestation of androgenesis. Our results confirm the effect of the presence of $L r 19$ gene on androgenesis. It has been observed that genotypes with translocation sequence carrying the $L r 19$ gene stimulated the induction of embryolike structures, but increased green plant regeneration, compared with the previously reported studies (Weigt et al., 2012).

The factor severely limiting anther cultures is the regeneration of plants with chlorophyll defects (Kim et al., 2003; Kondić-Špika et al., 2008). In some wheat genotypes, the frequency of albino plants' formation ran- 
ged from $20 \%$ to $50 \%$ (Tadesse et al., 2012). Zamani and coworkers (2000) argue that the presence of albino plants in anther cultures depended on the genotype, whether or not possessing the ability to perform androgenesis and/or green plant regeneration. In our experiments, the quantity of albino plants with respect to all obtained plants was 50\%. Masojc and coworkers (1993) observed higher appearance of albino plants-on average $63 \%$ in anther cultures of wheat. Interestingly, Zamani and coworkers (2000), through colchicine application to the induction medium at the beginning of the induction phase of androgenesis, obtained a significantly lower proportion of albino plants (1.4-26.8\%). Barnabas and coworkers (1991) suggested that colchicine can selectively eliminate microspores carrying anomalies that cause albino plants to grow. In our experiments, the T36 $\times$ Hondia cross produced plants with chlorophyll defects with more than three times higher frequency than the T39 $\times$ Ozon plants. Since in our experiments, $\operatorname{Lr} 19$ gene is present in both tested genotypes, we conclude that this gene did not influence the formation of albino plant. Sibikeeva and Sibikeev (2014) came to a similar conclusion and suggested that the frequency of the formation of albino plants did not depend on plants' genotypes but on the growth conditions. In our investigation, we observed that higher number of albino plants was formed on a medium with the addition of kinetin.

The most commonly used hormone combination in androgenesis experiments is 2,4-D with the addition of kinetin (Zamani et al., 2000; Chaudhary et al., 2003; Konieczny et al., 2005; Weigt et al., 2012). The Potato-II (Dobrovolskaya et al., 2001, 2003; Pershina et al., 2013) and $\mathrm{N}_{6}$ (Sibikeeva et al., 2004, 2014) induction media with the addition of 2,4-D at different concentrations are the most commonly used. Based on the previous research (data not published), C17 induction media with three combinations of growth hormones were used in our study. However, different combinations of hormones had no impact on the frequency of formation of embryolike structures and on the regeneration frequency of plant in both green and albino types. According to the results of Mendoza and Kaeppler (2002) and Weigt and coworkers (2012), the ability to form green wheat plants was the highest on medium with dicamba, and the frequency of this process was $2.02 \%$, on average. In the Mendoza and Kaeppler (2002) experiment, an application of 2,4-D and dicamba to the medium resulted in a twofold increase in the number of plants regenerated per embryo and reduced the amount of time required for plant regeneration by 3-4 weeks. The addition of kinetin to the induction medium in our study resulted in an increase in average effectiveness of albino plant regeneration.

The most important advantage of the anther culture method is the occurrence of spontaneous chromosome doubling that results in the production of homozygous DH lines (Kondić-Špika et al., 2008). Spontaneously doubled $\mathrm{DH}$ lines are fertile and do not require colchicine treatment. Most of them are cytologically stable, except for small percentage of them, which exhibit chromosomal abnormalities. Our experiment included 55 spontaneous DH plants and 10 aneuploid plants from 162 tested on ploidy level. The spontaneous doubling did not depend on hormones present in induction media but on the plant genotype.

\section{Conclusions}

A significant effect of genotype on the regeneration of embryo-like structure was observed. The T36 $\times$ Hondia $\mathrm{F}_{3}$ anthers produced more embryo-like structures (reaching the frequency of $11.58 \%$ ) than the T39 $\times$ Ozon $\mathrm{F}_{3}$ anthers, where the frequency was $6.44 \%$.

The impact of growth hormone on the formation of embryo-like structure and the regeneration frequency of green plant was not significant. In three analyzed combinations of growth regulators in induction media, the frequency of formation of embryo-like structure ranged from $9.42 \%$ to $10.31 \%$ and the regeneration frequency of plant ranged from $1.01 \%$ to $1.79 \%$.

\section{Acknowledgments}

The research was carried out under the NCBR project-PBS2/ A8/25/2013-implemented within the consortium BIOTRIGEN.

\section{References}

Baenziger S., Kim K.M., Haliloglu K. (2001) Wheat in vitro breeding. The world wheat book: A history of wheat breeding. Intercept Limagrain New York: 979-1000.

Barnabas B., Pfahler P.L., Kovacs G.(1991) Direct effect of colchicine on microspore embryogenesis to produce dihaploid plant in wheat (Triticum aestivum L.). Theor. Appl. Genet. 81: 675-678.

Barnabas B., Szakacs E., Karsai I., Bedö Z. (2001) In vitro androgenesis of wheat: from fundamentals to practical application. Euphytica 119: 211-216. 
Broughton S. (2011) The application of n-butanol improves embryo and green plant production in anther culture of Australian wheat (Triticum aestivum L.) genotypes. Crop Pasture Sci. 62: 813-822.

Chaudhary H.K., Dhaliwal I., Singh S., Sethi G.S. (2003) Genetics of androgenesis in winter and spring wheat genotypes. Euphytica 132: 311-319.

Dobrovolskaya O.B., Pershina L.A., Kravstova L.A., Silkova O.G., Shchapova A.I. (2001) The effect of rye chromosomes on the characteristic features of androgenesis in wheat-rye substitution lines Triticum aestivum L. (cv. Saratovskaya 29)/Secale cereal L. (cv. Onokhoiskaya) and Triticale. Russ. J. Genet. 37(5): 506-512.

Dobrovolskaya O.B., Pershina L.A., Kravstova L.A., Shchapova A.I. (2003) Comparative effects of rye chromosomes $1 R$ and $5 R$ on androgenesis in cultured anthers of wheat-rye substitution lines as dependent on the line origin. Russ. J. Genet. 39(4): 467-470.

Hussain M., Niaz M., Iqbal M., Iftikhar T., Ahmad J. (2012) Emasculation techniques and detached tiller culture in wheat $x$ maize crosses. J. Agricult. Res. 50: 1-19.

Kasha K.J. (2005) Chromosome doubling and recovery of doubled haploid plants. In Haploids in crop improvement II: 123-152. Springer Berlin Heidelberg.

Kim K.M., Baenziger S.P., Rybczynski J.J. (2003) Characterization of ploidy levels of wheat microspore-derived plants using laser flow cytometry. In Vitro Cell. Dev. Biol.Plant 39: 663-668.

Kondić-Špika A.D., Kobiljski B.D., Hristov N.S. (2008) Efficiency of anther culture technique in the production of wheat double haploids. Proc. Nat. Sci. Matica Srpska Novi Sad. 115: 35-40.

Kondić-Špika A., Vukosavljev M., Kobiljski B., Hristov N. (2011) Relationships among androgenetic components in wheat and their responses to the environment. J. Biol. Res. Thessal. 16: 217-223.

Konieczny R., Bohdanowicz J., Czaplicki A.Z., Przywara L. (2005) Extracellular matrix surface network during plant regeneration in wheat anther culture. Plant Cell Tiss. Org. Cult. 83: 201-208.

Kryczyński S., Weber Z. (red.). (2011) Fitopatologia. T. 2. Choroby roślin uprawnych. PWRiL, Poznań, 464 ss.

Lantos C., Weyen J., Orsini, J.M., Gnad H., Schlieter B., Lein V., Kontowski S., Jacobi A., MihÁly R., Broughton S., Pauk J. (2013) Efficient application of in vitro anther culture for different European winter wheat (Triticum aestivum L.) breeding programmes. Plant Breed. 132: 149-154.

Marciniak K., Kaczmarek Z., Adamski T., Surma M. (2003) The anther culture response of Triticale line $\mathrm{x}$ tester progenies. Cellular, Mol. Biol. Lett. 8: 343-351.

Masojc P., Lukow O.M., McKenzie R.I.H., Howes N.K. (1993) Responsiveness to anther culture in cultivars and $F_{1}$ crosses of spring wheat. Can. J. Plant Sci. 73: 777-783.

McIntosh R.A., Wellings C.R., Park R.F. (1995) Wheat Rusts. An Atlas Of Resistance Genes. CSIRO, Australia: 1-86.
McIntosh R.A., Yamazaki Y., Dubcovsky J., Rogers W.J., Morris C., Appels, R., Devos, K.M. (2010) Catalogue of gene symbols for wheat: 2010. In KOMUGI Integrated Wheat Science Database. Available online: www.shigen.nig.ac.jp/ wheat/komugi/genes (accessed 17 October 2012)

Mendoza M.G., Kaeppler H.F. (2002) Auxin and sugar effects on callus induction and plant regeneration frequencies from mature embryos of wheat (Triticum aestivum L.). In Vitro Cell. Dev. Biol. - Plant 38: 39-45.

Murashige T., Skoog F. (1962) A revised medium for rapid growth and bioassays with tobacco tissue cultures. Physiol. Plant 15 (3): 473-497.

Niroula R.K., Bimb H.P. (2009) Overview of 1 wheat $x$ maize system of crosses for dihaploid induction in wheat. World Appl. Sci. J. 7: 1037-1045.

Pauk, J., Kertész, Z., Beke, B., Bóna, L., Csősz, M., Matuz, J. (1995) New Winter Wheat Variety: 'GK Délibáb' Developed via Combining Conventional Breeding and In Vitro Androgenesis. Cereal Res. Commun. 23(3): 251-256.

Pershina L.A., Osadchaya T.S., Badaeva E.D., Belan I.A., Rosseeva L.P. (2013) Androgenesis in anther cultures of cultivars and a promising form of spring common wheat of west Siberia differing in the presence or absence of wheat-alien translocations. Russ. J. Genet. Appl. Res. 17(1): 40-49.

R Core Team. (2015). R: A Language and Environment for Statistical Computing. R Foundation for Statistical Computing. Vienna, Austria. https://www.R-project.org.

Redha A., Suleman P. (2011) Effects of exogenous application of polyamines on wheat anther cultures. Plant Cell Tiss. Organ Cult. 105: 345-353.

Rybczyński J.J., Simonson R.L., Baezinger P.S. (1991) $E_{V i-}$ dence for microspore embryogenesis in wheat anther culture. In vitro Cell. Dev. Biol. 27: 168-174.

Sibikeeva Y.E., Sibikeev S.N. (1996) Genetic analysis of anther culture response in wheat carrying alien translocations. Theoret. Appl. Genet. 92(6): 782-785.

Sibikeeva Y.E., Sibikeev S.N., Krupnov V.A. (2004) The effect of Lr19-translocation on in vitro androgenesis and inheritance of leaf-rust resistance in DH3 lines and $F_{2}$ hybrids of common wheat. Russ. J. Genet. 40(9): 1003-1006.

Sibikeeva Y.E., Sibikeev S.N. (2014) The influence of combinations of alien translocations on in vitro androgenesis in near-isogenic lines of spring bread wheat. Russ. J. Genet. 50(7): 728-735.

Śliwińska E. (2008) Estimation of DNA Content in Plants Using Flow Cytometry. Post. Biol. Komórki 35(24): 165176.

Tadesse W., Inagaki M., Tawkaz S., Baum M., Van Ginkel M. (2012) Recent advances and application of doubled haploids in wheat breeding. Afr. J. Biotech. 11(89): 1548415492.

Torp A.M., Hansen A.I., Andersen S.B. (2001) Chromosomal regions associated with green plant regeneration in wheat (Triticum aestvum L.) anther culture. Euphytica 119: 377387. 
Wang P, Chen Y. (1983) Preliminary study on production of height of pollen H2 generation in winter wheat grown in the field. Acta Agron. 9: 283-284.

Weigt D., Nawracała J., Popowska D., Nijak K. (2012) Examination of ability to androgenesis of spring wheat genotypes resistant to Fusarium. BioTechnologia 93(2): 116-122.
Zamani I., Kovacs G., Gouli-Vavdinoudi E., Roupakias D.G., Barnabas B. (2000) Regeneration of fertiledoubled haploid plants from colchicine supplemented media in wheat anther culture. Plant Breeding 119: 461-465. 